\title{
Effects of Diet Containing Fermented Canola Meal on Performance, Blood Parameters, and Gut Health of Broiler Chickens
}

\author{
Ahmed Mohamed Elbaz \\ Poultry Nutrition, Desert Research Center, Cairo, Egypt \\ *Corresponding author's Email: dm.a.baz@gmail.com; ORCID: 0000-0002-2207-8912
}

\begin{abstract}
The current research aimed to study the effects of the fermented canola meal (Lactobacillus) diet on productive performance, blood parameters, and gut health of broiler chickens under high ambient temperature conditions. A total number of 320 (Ross-308) one-day-old broiler chickens were allocated randomly into four experimental groups for 42 days. Four experimental groups with four types of diet, including the control group (CON) received basal diet, and three other experimental groups were supplemented with $20 \%$ of the canola meal (CM), $20 \%$ fermented canola meal (FCM), and 20\% canola meal with probiotic (PCM). The chickens that fed FCM presented improvement in live body weight, feed conversion ratio, and higher nutrient digestibility, compared to CM and PCM groups. Serum glucose, total protein, albumin, and aspartate aminotransferase (AST) of levels of chickens fed by FCM were higher than chickens fed CM and PCM, while there was a decrease in cholesterol. Fermented canola meal resulted in some noticeable beneficial changes in the cecum microflora communities through increasing the population of Lactobacillus spp. and decreasing the Escherichia coli and improved its morphology by increasing villus height. The results indicated that the fermentation of canola meal has enhanced performance, nutrient digestibility, and gut health, which allow using greater amounts of fermented canola meal as a replacement of soybeans meal in the broiler diet.
\end{abstract}

Keywords: Broiler, Canola meal, Fermentation, Gut health, Performance, Serum parameter

\section{INTRODUCTION}

The increase in the price of feed ingredients during recent years in Egypt had a strong impact on the production cost of the poultry industry. This issue could put breeders under pressure since most of the feed ingredients are imported from abroad. Agricultural waste and oil extraction waste are a source of environmental pollution for their enormous quantities, which are useless and difficult to dispose of. This has compelled nutritionists to explore any viable method for incorporating alternative feedstuffs in poultry diets. Protein and energy sources in poultry feed are the most important and expensive ones; however, the protein sources are more expensive. Several studies have focused on the efficient use of alternative plant protein sources, or agricultural waste (unconventional feed ingredients). However, many problems would be encountered in the use of these alternatives such as antinutritional factors, low protein contents, and high fiber, which affect utilization and digestion of feed in monogastric (Alshelmani et al., 2016; Zhang et al., 2016). The chicken's digestive tract produces no enzymes to hydrolyze crude fiber, therefore, the utilization of unconventional feed ingredients in the chickens' diet would be limited and in need of processing.

Hence, many researchers have thought about solving these problems either by heat, or fermentation. As a result of the developments in microbiology, the poultry feed industry has found an effective method to improve the utilization of some unconventional feed ingredients through the fermentation process. Many studies indicated that the fermentation process leads to an increase in crude protein content, a decrease in antinutritional factors (such as tannins and glucosinolates), and crude fiber content (Mukherjee et al., 2016; Soumeh et al., 2019). One of the most important and effective methods to eliminate the antinutritional factors in unconventional feed ingredients is through fermentation, which improves its nutritional value (Croat et al., 2016; Mahata et al., 2019). Many studies presented that the fermentation process or adding microorganisms enhanced digestive enzyme activities and modulation of the immune system, improved intestinal morphology, increased gut beneficial microbes, and prevented the colonization of enteropathogens through 
competitive exclusion and antagonistic activities leading to an improvement in growth performance (Chachaj et al., 2019; Mahata et al., 2019; Abdel-Moneim et al., 2020). Additionally, the fermentation process effectively reduces the glucosinolates level of Rapeseed Meal (RSM, Hu et al., 2016), hence, fermentation may improve the nutritional value of RSM when presented in broiler feeds. The current study was conducted to evaluate the performance, plasma biochemistry variables, intestinal microflora, and histomorphology of broilers fed with Fermented Canola Meal (FCM) and also to determine the possibility of using fermented canola meal (CM) at $20 \%$ as a replacement of soybean meal in broiler diet.

\section{MATERIALS AND METHODS}

\section{Ethical approval}

The current experiment was conducted at the poultry farm of the Poultry Research Unit (Siwa station) following the instructions of the Experimental Animals Care Committee, approved by the Institutional Ethics Committee, Desert Research Center, Egypt.

\section{Fermentation of canola meal}

Canola meal was purchased from the Desert Research Center Environmental Division. The Lactobacillus fermentum (CGMCC No. 0843) was brought from the Department of Microbiology, Faculty of Agriculture, Ain Shams University, Egypt. The required amount of canola meal for the experiment was weighed (80 kilograms) and mixed with distilled water (to raise the humidity) then mixed with the microbe (at a rate of 1 gram per kilogram of canola meal), placed the mixture in a polythene bag (5kg capacity), and created suitable anaerobic conditions to activate the L. Fermentum followed by 30-day incubation at room temperature (ranging from 30 to $32^{\circ} \mathrm{C}$ ). The fermented canola was dried in the oven at $45^{\circ} \mathrm{C}$ for 3 days (Rodriguez-Leon et al., 2008). The freshly dried fermented canola was ground and kept at room temperature for chemical analysis and preparing the diets.

\section{Chemical analysis of canola meal and fermented canola meal}

The CM and FCM samples were analyzed for their chemical composition in the official accredited feed analysis laboratory in Egypt. Results indicated that crude protein increased from $36.31 \%$ in $\mathrm{CM}$ to $39.65 \%$ in $\mathrm{FCM}$ (Association of Official Analytical Chemists, 1990), crude fat increased from $1.61 \%$ to $2.18 \%$ (Wang et al., 2004).
Meanwhile, crude fiber ( $12.80 \%$ to $8.56 \%)$, tannin (1.53\% to $0.96 \%$ ), and total aflatoxin (36 ng/g to $22 \mathrm{ng} / \mathrm{g}$ ) decreased (determined according to Van Soest et al., (1991), International Organization for Standardization (1988), and Howell et al., (1981) respectively).

\section{Experimental design and chicken housing}

The presented experiment was conducted at the poultry farm of the Poultry Research Unit (Siwa station) for 42 days. The experiment started on August 10, 2019. A total number of 320, one-day-old broiler chicks (Ross-308, commercial hatchery, from a poultry company in Cairo, Egypt) were randomly allotted to cages (80 chickens in each group, four replicates of 20 chickens per each group) in a total of four treatments. The control chickens (CON) were fed with a corn-soybean diet, and three other experimental diets were supplemented with $20 \%$ of the Canola Meal (CM), 20\% Fermented Canola Meal (FCM), and 20\% Canola Meal with Probiotic (PCM) to replace part of soybean meal. Lactobacillus fermentum 1 kilo/ton was added as a source of probiotic. The starter (1-21 days) and grower (22-42 days) diets were formulated as presented in Table 1. The experimental diets were formulated to meet the nutritional requirements of the chickens at each phase of development according to the recommendations of the National Research Council (NRC, 1994). The diets and water were provided ad libitum for 42 days. The lighting for each cage was 60 -watt for 24 hours in the first week and 22 hours until the end of the experiment. The chickens were vaccinated against Newcastle disease at the age of 7, 19, and 30 days as well as gumboro disease at the age of 15 days, and against influenza at the age of seven days. The chickens were raised at $33.0 \pm 1{ }^{\circ} \mathrm{C}$ for the first three days, and then the temperature was gradually reduced to $30.5 \pm 1^{\circ} \mathrm{C}$ by day 10 , then left with ambient temperatures to the end of the experiment.

\section{Growth performance and nutrient digestibility}

At the age of 42 days, Live Body Weight (LBW), and Feed Intake (FI) were recorded individually for each replicate, and used to calculate Feed Conversion Ratio (FCR). At the end of the experiment, four chickens from each experimental group were randomly selected for slaughtering to measure the carcass traits. The percentage of carcass yield, spleen, gizzard, heart, abdominal fat, thymus, bursa of Fabricius, and small intestine relative weights were measured. At the age of 42 days, the digestion experiment started. Four chickens from each treatment group were weighed and housed in metabolic 
cages individually then starved for 12 hours. During the age of 42 to 45 days, unpolluted excreta were collected, three times a day from the bottom of each cage, weighed dried, and then froze $\left(-20{ }^{0} \mathrm{C}\right)$ to analyze and measure the digestibility determination for Crude Protein (CP) and Dry Matter (DM) according to Association of Official Analytical Chemists, (AOAC, 2003) which are presented in Table 2.

\section{Biochemical serum analysis}

Blood samples were collected at the age of 42 days from the wing vein before slaughtering. Blood samples were collected from four chickens of each experimental group then centrifuged at $3000 \mathrm{rpm}$ for $15 \mathrm{~min}$ to obtain the serum and then the serum was stored at $-10^{\circ} \mathrm{C}$ until analyzed. Cholesterol, total protein, triglycerides, glucose, albumin, uric acid, and hepatic enzyme activity (Alanine aminotransferase [ALT], and Aspartate aminotransferase [AST]) were estimated using an automatic biochemical analyzer (CX9, Beckman).

\section{Microflora and histomorphology}

Cecal samples were taken for a microbial count as described by Zhu et al. (2002) to investigate gut health. Four chickens from each group (one from each replicate) were selected as above, the caecum was quickly dissected, and $3 \mathrm{~g}$ of their contents were collected in sterilized sampling tubes. Then, 10-fold serial dilutions of one $\mathrm{g}$ of sample were serially made in phosphate buffer solution. Subsequently, $100 \mu \mathrm{l}$ were removed from $10^{-4}, 10^{-5}$, and $10^{-6}$ dilutions, and poured onto Petri dishes containing the agar (culture media). Escherichia coli were cultured in eosin methylene blue agar and incubated at $37^{\circ} \mathrm{C}$ for 48 hours under aerobic conditions. Lactobacilli were cultured in De Man, Rogosa, and Sharpe's agar and incubated at 37 ${ }^{\circ} \mathrm{C}$ for 72 hours under anaerobic conditions. Cecal contents were counted for microbial populations using a conventional method (spread plate method) by Casagrande Proietti et al. (2009). Histological slides were prepared to form the ileum samples of the slaughtered chickens (approximately $2 \mathrm{~cm}$ taken from the ileum mid-part). Segments were fixed in $10 \%$ neutral buffered formalin solution and were embedded in paraffin wax. Parts of the ileum were prepared and placed on a glass slide and stained with Alcian Blue stain. Histological evidence (villus height and crypt depth) slides were examined by using the electron light microscope (ZEISS Axio Imager A2, Germany ) after stained with Haematoxylin and Eosin.

\section{Statistical analysis}

Data were analyzed using the analysis of variance in SAS (2002) followed by performing the Duncan Multiple Range Test. The chosen level of significance for all comparisons was $\mathrm{p}<0.05$.

Table 1. Ingredient composition and nutrient content of different experimental diets

\begin{tabular}{|c|c|c|c|c|c|c|c|c|c|}
\hline & & \multicolumn{4}{|c|}{$\begin{array}{c}\text { Starter } \\
\text { (day } 1 \text { to } 21)\end{array}$} & \multicolumn{4}{|c|}{$\begin{array}{c}\text { Grower } \\
\text { (day } 22 \text { to } 42 \text { ) }\end{array}$} \\
\hline & & CON & $\mathbf{C M}$ & PCM & FCM & CON & $\mathbf{C M}$ & PCM & FCM \\
\hline \multirow{8}{*}{$\begin{array}{l}\text { Ingredient } \\
(\%)\end{array}$} & Soybean meal (48\%) & 32.50 & 17.55 & 17.55 & 17.54 & 26.55 & 13.10 & 13.10 & 12.64 \\
\hline & Canola meal (CM) & 00.00 & 20.00 & 20.00 & 00.00 & 00.00 & 20.00 & 20.00 & 00.00 \\
\hline & Corn oil & 1.50 & 2.90 & 2.90 & 2.95 & 3.10 & 4.85 & 4.85 & 4.85 \\
\hline & Di calcium phosphate & 2.20 & 2.20 & 2.20 & 2.20 & 1.90 & 1.80 & 1.80 & 1.80 \\
\hline & Calcium Carbonate & 1.20 & 1.15 & 1.15 & 1.15 & 1.15 & 1.05 & 1.05 & 1.05 \\
\hline & Premix * & 0.30 & 0.30 & 0.30 & 0.30 & 0.30 & 0.30 & 0.30 & 0.30 \\
\hline & Salt & 0.25 & 0.25 & 0.25 & 0.25 & 0.25 & 0.25 & 0.25 & 0.25 \\
\hline & DL-methionine & 0.14 & 0.12 & 0.12 & 0.10 & 0.13 & 0.09 & 0.09 & 0.10 \\
\hline \multirow{3}{*}{$\begin{array}{l}\text { Calculated } \\
\text { composition }\end{array}$} & $\mathrm{CP}$ & 23 & 23 & 23 & 23 & 21 & 21 & 21 & 21 \\
\hline & Calcium & 1.0 & 1.0 & 1.0 & 1.0 & 0.95 & 0.95 & 0.95 & 0.95 \\
\hline & Available Phosphorus & 0.5 & 0.5 & 0.5 & 0.5 & 0.45 & 0.45 & 0.45 & 0.45 \\
\hline
\end{tabular}

* Vitamin A 12,000 IU, Vitamin D3 3,000 IU, Vitamin E 40 mg, Vitamin K3 3 mg, Vitamin B1 2 mg, Vitamin B2 6 mg, Vitamin B6 5 mg, Vitamin B12 0.02 $\mathrm{mg}$, niacin $45 \mathrm{mg}$, biotin $0.075 \mathrm{mg}$, folic acid $2 \mathrm{mg}$, pantothenic acid $12 \mathrm{mg}$, manganese $100 \mathrm{mg}$, zinc $600 \mathrm{mg}$, iron $30 \mathrm{mg}$, copper $10 \mathrm{mg}$, iodine $1 \mathrm{mg}$, selenium $0.2 \mathrm{mg}$, cobalt $0.1 \mathrm{mg}$. **Metabolizable energy for canola meal (kcal/kg) 2,000, CON: Control, CM: Canola Meal, FCM: Fermentation Canola Meal. CP: Crude Protein, Metabolizable energy for canola meal $(\mathrm{kcal} / \mathrm{kg}) 2,000$ 
Elbaz et al., 2021

Table 2. Growth performance and nutrient digestibility of broiler chickens fed different experimental diets for 42 days

\begin{tabular}{llcccccc}
\hline & & CON & CM & PCM & FCM & SEM & p value \\
\hline \multirow{2}{*}{ Growth performance (g) } & Live body weight & $2066^{\mathrm{a}}$ & $1957^{\mathrm{c}}$ & $2034^{\mathrm{b}}$ & $2081^{\mathrm{a}}$ & 31.50 & 0.022 \\
& Feed intake & 3398 & 3367 & 3382 & 3401 & 18.66 & 0.170 \\
& Feed conversion ratio & $1.645^{\mathrm{bc}}$ & $1.719^{\mathrm{a}}$ & $1.667^{\mathrm{b}}$ & $1.633^{\mathrm{c}}$ & 0.091 & $<0.001$ \\
\hline \multirow{2}{*}{ Nutrient digestibility (\%) } & Dry matter & $87.15^{\mathrm{a}}$ & $81.38^{\mathrm{c}}$ & $83.95^{\mathrm{b}}$ & $88.03^{\mathrm{a}}$ & 0.860 & 0.028 \\
& Crude protein & $78.33^{\mathrm{ab}}$ & $72.5^{\mathrm{c}}$ & $76.06^{\mathrm{b}}$ & $80.43^{\mathrm{a}}$ & 0.944 & 0.006 \\
\hline
\end{tabular}

$\overline{a, b, c}$ : Means in the same row with different superscripts are significantly different at $\mathrm{p}<0.05$. CON: control (without canola), CM: $20 \%$ canola meal, FCM: $20 \%$ fermentation canola meal, PCM: $20 \%$ canola meal with probiotic, SEM: Standard Error of Means

\section{RESULTS AND DISCUSSION}

Productive performance, nutrient digestibility, and carcass traits are presented in Tables 2 and 3. Nutrient digestibility of DM and CP were significantly higher $(\mathrm{p}<0.05)$ for chickens fed FCM than those fed unfermented canola meal. Previous studies indicated that the fermentation process helps with increasing crude protein and crude fat content (Wang et al., 2010). As a result, fermenting CM should reflect beneficial effects on the health and performance of chickens. Statistical analysis of the data indicated a better digestibility of DM and $\mathrm{CP}$ in diets containing FCM, compared to the other experimental groups. The same results were reported by Afsharmanesh et al. (2010) who stated that there was an improvement in nutrient utilization in chickens fed with diets containing yeast. The higher nutrient digestibility might be due to the reduction in pathogenic load (modulator microbial content) in the gut which led to a positive effect on the absorption of nutrients and improved nutritional value (Khidr et al., 2017).

The chickens fed FCM presented significantly higher LBW and an enhanced FCR, compared to chickens fed with $\mathrm{CM}$ and PCM $(\mathrm{p}<0.05)$. Feed intake decreased in the broilers fed CM, compared to groups fed PCM and FCM. These findings were in agreement with the earlier findings of Feng et al. (2007) Mathivanan et al. (2006) who observed a significant difference in body weight due to the fermentation of the broiler diet. Significant improvements in performance parameters of broiler chickens might be caused by the enhancement of nutritional quality and lowering the content of antinutritional factors in the fermented canola meal. Similar improvements in productive performances were reported by Chiang et al. (2010) with the fermentation of unconventional feed ingredients in broilers.

There was an increase in carcass yield and relative weight of the small intestine, and a decrease in the abdominal fat of the FCM group, compared to CM and
PSM groups (Table 3). The relative weight of Bursa of Fabricius was significantly higher in FCM and PCM groups ( $\mathrm{p}<0.05$ ), compared to $\mathrm{CM}$ and CON groups. However, there were no significant differences between different experimental diets on weights of spleen, liver, thymus, gizzard, and heart. The observed increase in carcass yield in FCM and PCM groups might be due to the positive effect of the fermentation process on nutrient utilization leading to more gain in body weight in the chickens of these groups. Those improvements could be a result of the cumulative effect of Lactobacillus in the fermentation process, including increasing digestive enzyme activity and balancing beneficial microbial populations in the gut environment to improve digestion and nutrient utilization (Shim et al., 2010). The increase in carcass weight is a result of adding beneficial bacteria to the diet which enhanced protein availability (Nahashon et al., 1996). The significant increase in the relative weight of the bursa of Fabricius in FCM and PCM groups might be due to an increase in the number of lymphocytes in primary lymphoid organs, as a result of the beneficial bacteria effect on the functional activities of the immune system which led to an improvement in the immune system responses of the chickens (Willis et al., 2007). The highest weight of the small intestine and the lowest abdominal fat $(\mathrm{p}<0.05)$ were observed in the chickens fed FCM. This positive effect of the beneficial microbes helps in a better distribution of fat in the carcass, which indicates that probiotics efficiently improve energy usage (Santoso et al., 1995).

Experimental treatments have affected serum biochemistry as presented in Table 4 . The chickens, which fed FCM and PCM had higher levels of glucose, total protein, and albumin than those fed a control diet and CM. The levels of cholesterol and triglycerides of FCM and PCM groups were significantly lower than those of control groups ( $\mathrm{p}<0.05)$. The concentration of AST increased in chickens fed FCM, compared to CON and other groups, while their values of Alanine aminotransferase were not 
affected ( $\mathrm{p}<0.05)$. In the current experiment, an increase in the level of the serum total protein and albumin was observed in broilers fed with FCM leading to an improvement in the deposition of protein in the tissues (Xu et al., 2012). The lower content of total serum cholesterol and triglycerides of broiler fed with FCM and PCM were observed, compared to other groups, which indicated that fermented $\mathrm{CM}$ feed might significantly improve the utilization of lipids in dietary. Studies by Hu et al., (2016) and Elbaz and ELshiekh (2020) showed a reduction in total serum cholesterol and triglycerides levels when the chickens were fed fermented diets or diets supplemented with probiotics. There was an increase in AST concentration in FCM chickens of the current study and this result was in agreement with Chachaj et al., (2019) who reported that fermented soybean meal increased the AST concentration in turkeys. The increase in the activity of the AST enzyme may be an indication of liver functional changes resulted from the increase in amino acid transforming rate during the metabolism of many tissues (Fevery, 2008). Microbial count results of cecal samples are presented in Table 5. Fermenting the diet had a significant effect on the microbial population in the gut. The total number of lactobacilli in the ceca of the chickens fed FCM and PCM were significantly higher; meanwhile, the numbers of Escherichia Coli were lower than those fed $\mathrm{CM}$ or the control diet. Similar observations were recorded by different studies (Engberg et al., 2009; Sun et al., 2013; Khidr et al., 2017). Similarly, fermented feeds may act similar to probiotics in improving gut health by balancing the microbial population (the competitive flora) and the production of organic acids by lactobacillus (Paton et al., 2006; Liang et al., 2012).

Morphological measurements of small intestines are presented in Table 5. An increase in villus height of ileum was noticeable in broilers fed with FCM and PCM (p < 0.05). However, chickens fed either FCM or PCM diet had lower crypt depth in the ileum than those fed CM or CON $(p<0.05)$. These results were similar to those recorded by Chiang et al., (2010) and Zhang et al., (2016) showed that feeding chickens on fermented rapeseed meal led to an increase in villus height. The increase in the weight of the intestine can also be explained by the increase in length villus height in the ileum in chickens fed with FCM. The beneficial changes in the morphology of the intestine led to an increase in the surface of absorption, and thus enhanced the absorption of nutrients, which could explain the improvement in the productive performance.

Table 3. Carcass traits and immune organic of broiler chickens fed different experimental diets

\begin{tabular}{llcccccc}
\hline Items & & CON & CM & PCM & FCM & SEM & p value \\
\hline & Carcass yield & $77.91^{\mathrm{a}}$ & $74.26^{\mathrm{b}}$ & $76.15^{\mathrm{ab}}$ & $78.22^{\mathrm{a}}$ & 0.751 & 0.020 \\
Carcass trite (g/100 & Liver & 2.76 & 2.63 & 2.94 & 3.09 & 0.089 & 0.295 \\
g body weight) & Heart & 1.82 & 1.70 & 1.72 & 1.74 & 0.052 & 0.791 \\
& Abdominal fat & 0.526 & 0.585 & 0.513 & 0.528 & 0.029 & 0.831 \\
& Small intestine & $1.82^{\mathrm{a}}$ & $1.79^{\mathrm{a}}$ & $1.80^{\mathrm{a}}$ & $1.67^{\mathrm{b}}$ & 0.075 & 0.037 \\
\hline Immune organic & Spleen & $3.43^{\mathrm{b}}$ & $2.89^{\mathrm{c}}$ & $3.72^{\mathrm{ab}}$ & $4.08^{\mathrm{a}}$ & 0.092 & 0.018 \\
(g/100 g body & Thymus & 0.114 & 0.095 & 0.166 & 0.148 & 0.010 & 0.094 \\
weight) & Bursa of Fabricius & 0.262 & 0.247 & 0.275 & 0.250 & 0.010 & 0.165 \\
\hline
\end{tabular}

$\overline{a, b, c}$ : Means in the same row with different superscripts are significantly different at $\mathrm{p}<0.05$. CON: control (without canola), CM: $20 \%$ canola meal, FCM: $20 \%$ fermentation canola meal, PCM: $20 \%$ canola meal with probiotic, SEM: Standard Error of Means.

Table 4. Serum biochemical parameters of broiler chickens fed different experimental diets

\begin{tabular}{lcccccc}
\hline Parameters & CON & CM & PCM & FCM & SEM & p value \\
\hline Glucose $(\mathrm{mmol} / \mathrm{L})$ & $7.16^{\mathrm{b}}$ & $6.78^{\mathrm{b}}$ & $9.65^{\mathrm{a}}$ & $10.08^{\mathrm{a}}$ & 0.041 & 0.032 \\
Cholesterol $(\mathrm{mmol} / \mathrm{L})$ & $2.92^{\mathrm{a}}$ & $3.55^{\mathrm{a}}$ & $2.14^{\mathrm{b}}$ & $1.97^{\mathrm{b}}$ & 0.038 & 0.014 \\
Triglycerides $(\mathrm{mmol} / \mathrm{L})$ & $0.51^{\mathrm{a}}$ & $0.37^{\mathrm{b}}$ & $0.46^{\mathrm{ab}}$ & $0.42^{\mathrm{ab}}$ & 0.093 & 0.040 \\
Total protein $(\mathrm{g} / \mathrm{L})$ & $27.80^{\mathrm{ab}}$ & $23.73^{\mathrm{b}}$ & $28.13^{\mathrm{ab}}$ & $30.73^{\mathrm{a}}$ & 1.188 & 0.019 \\
Albumin $(\mathrm{g} / \mathrm{L})$ & $12.26^{\mathrm{ab}}$ & $8.24^{\mathrm{b}}$ & $11.76^{\mathrm{b}}$ & $13.96^{\mathrm{a}}$ & 0.677 & 0.000 \\
Uric acid $(\mu \mathrm{mol} / \mathrm{L})$ & 178.15 & 169.95 & 196.20 & 201.05 & 4.595 & 0.169 \\
ALT $\left(\mathrm{U} .1^{-1}\right)$ & 45.24 & 47.84 & 40.50 & 41.02 & 6.657 & 0.205 \\
AST $\left(\mathrm{U} .1^{-1}\right)$ & $161.5^{\mathrm{a}}$ & $140.9^{\mathrm{b}}$ & $155.0^{\mathrm{ab}}$ & $169.3^{\mathrm{a}}$ & 5.775 & 0.023 \\
\hline
\end{tabular}

$\overline{a, b, c}$ : Means in the same row with different superscripts are significantly different at $\mathrm{p}<0.05$. CON: Control (without canola), CM: $20 \%$ canola meal, FCM: $20 \%$ fermentation canola meal, PCM: 20\% canola meal with probiotic. ALT: Alanine aminotransferase, AST: Aspartate aminotransferase, SEM: Standard Error of Means. 
Elbaz et al., 2021

Table 5. Morphology and microbial counts of the cecum of broiler chickens fed different experimental diets

\begin{tabular}{|c|c|c|c|c|c|c|c|}
\hline Items & & CON & $\mathbf{C M}$ & PCM & FCM & SEM & p value \\
\hline \multirow{2}{*}{ Morphology $(\mu \mathrm{m})$} & Villus height & $545.60^{\mathrm{b}}$ & $536.00^{\mathrm{b}}$ & $585.57^{\mathrm{a}}$ & $599.60^{\mathrm{a}}$ & 42.9 & 0.001 \\
\hline & Crypt depth & $125.61^{\mathrm{a}}$ & $127.50^{\mathrm{a}}$ & $116.94^{\mathrm{b}}$ & $117.67^{\mathrm{b}}$ & 25.0 & 0.030 \\
\hline \multirow{2}{*}{$\begin{array}{l}\text { Microbial counts } \\
(\log 10 \mathrm{CFU} \text { g-1 } \\
\text { digesta) }\end{array}$} & Lactobacilli & $6.52^{\mathrm{b}}$ & $6.30^{\mathrm{b}}$ & $7.14^{\mathrm{ab}}$ & $8.49^{\mathrm{a}}$ & 0.35 & 0.050 \\
\hline & Escherichia coli & $2.49^{\mathrm{ab}}$ & $3.15^{\mathrm{a}}$ & $1.87^{\mathrm{b}}$ & $1.75^{\mathrm{b}}$ & 0.40 & 0.030 \\
\hline
\end{tabular}

a, b,c: Means in the same row with different superscripts are significantly different at p < 0.05 . CON: control (without canola), CM: $20 \%$ canola meal, FCM: $20 \%$ fermentation canola meal, PCM: $20 \%$ canola meal with probiotic, SEM: Standard Error of Means

\section{CONCLUSION}

The results obtained from the current study indicate that fermenting canola meal (Lactobacillus spp.) in broiler diets resulted in a beneficial effect on performance traits, which include an improvement in body weight gain, feed conversion ratio, nutrient digestibility, and gut health. Therefore, it can be concluded that using fermented canola meal in broiler diets might be effective to achieve the maximum benefits in broiler production by reducing dietary costs.

\section{DECLARATIONS}

\section{Competing interests}

The author has declared that there was no conflict of interest in the current research work.

\section{Acknowledgments}

The author would like to thank Atef Abdel-radi head of Siwa station for his cooperation while conducting the scientific experiment.

\section{REFERENCES}

Abdel-Moneim AE, Elbaz AM, Khidr RE, and Badri FB (2020). Effect of in ovo inoculation of Bifidobacterium spp. on growth performance, thyroid activity, ileum histomorphometry and microbial enumeration of broilers. Probiotics and Antimicrobial Proteins, 12: 873-882. DOI: https://link.springer.com/article/10.1007/s12602-019-09613-x

Afsharmanesh M, Barani M, and Silversides F (2010). Evaluation of wetfeeding wheat-based diets containing Saccharomyces cerevisiae to broiler chickens. British poultry science, 51(6): 776-783. DOI: https://www.doi.org/10.1080/00071668.2010.531006

Alshelmani MI, Loh TC, Foo HL, Sazili AQ, and Lau WH (2016). Effect of feeding different levels of palm kernel cake fermented by Paenibacilluspolymyxa ATCC 842 on nutrient digestibility, intestinal morphology, and gut microflora in broiler chickens. Animal Feed Science and Technology, 216: 216-224. https://www.doi.org/10.1016/j.anifeedsci.2016.03.019

Association of Official Analytical Chemists (1990). Official Methods of Analysis (15th ed.). Assoc. Off. Anal. Chem., Washington, DC. Vol. $15 . \quad$ Available at:
https://www.scirp.org/(S(czeh2tfqyw2orz553k1w0r45))/reference/ ReferencesPapers.aspx?ReferenceID $=1929875$

Association of Official Analytical Chemists (2003). Official methods of analysis of AOAC, (AOAC,Gaithersburg). Available at: https://www.worldcat.org/title/official-methods-of-analysis-ofaoac-international/oclc/476567963

Casagrande Proietti P, Dal Bosco A, Hilbert F, Franciosini MP, and Castellini C (2009). Evaluation of intestinal bacterial flora of conventional and organic broilers using culture-based methods. Italian Journal of Animal Science, 8(1): 51-63. DOI: https://www.doi.org/10.4081/ijas.2009.51

Chachaj R, Sembratowicz I, Krauze M, Stępniowska A, RusinekPrystupa E, Czech A, Matusevičius P, and Ognik K (2019). The effect of fermented soybean meal on performance, and biochemical and immunological blood parameters in turkey. Annals of Animal Sciences., 19: 1035-1049. DOI: https://www.doi.org/10.2478/aoas2019-0040

Chiang G, Lu W, Piao X, Hu J, Gong L, and Thacker P (2010). Effects of feeding solid-state fermented rapeseed meal on performance, nutrient digestibility, intestinal ecology and intestinal morphology of broiler chickens. Asian-Australasian Journal of Animal Sciences, 23(2): 263-271. DOI: https://www.doi.org/10.5713/ajas.2010.90145

Croat JR, Gibbons WR, Berhow M, Karki B, and Muthukumarappan K (2016). Enhancing the nutritional value of canola (Brassica napus) meal using a submerged fungal incubation process. Journal of Food Research, 5: 1-10. DOI: https://www.doi.org/10.5539/jfr.v5n5p1

Elbaz AM, and ELshiekh SA (2020). Effect of dietary probiotic, antibiotic or combination on broiler performance, cecum microbial population and ileal development. Mansoura Veterinary Medical Journal, $\quad$ 21(3):74-79. DOI: https://www.doi.org/10.35943/mvmj.2020.21.313

Engberg RM, Hammershøj M, Johansen NF, Abousekken MS, Steenfeldt S, and Jensen BB (2009). Fermented feed for laying hens: effects on egg production, egg quality, plumage condition and composition and activity of the intestinal microflora. British Poultry Science, 50: 228-239. DOI: https://www.doi.org/10.1080/00071660902736722

Feng, J., Liu X., Xu, Z. R., Wang Y. Z., and Liu J. X (2007). Effects of fermented soybean meal on digestive enzyme activities and intestinal morphology in broilers. Poultry Science, 86: 1149-1154. DOI: https://www.doi.org/10.1093/ps/86.6.1149

Fevery J (2008). Bilirubin in clinical practice: a review. Liver $\begin{array}{llll}\text { International, } & 28(5): & 592-605 . & \text { DOI: }\end{array}$ https://www.doi.org/10.1111/j.1478-3231.2008.01716.x

Howell, M. V., and Taylor, P. W. (1981). Determination of aflatoxins, ochratoxin A, and zearalenone in mixed feeds, with detection by thin layer chromatography or high performance liquid chromatography. Journal of the Association of Official Analytical Chemists, 64(6), 1356-1363. DOI: https://www.doi.org/10.1093/jaoac/64.6.1356

Hu Y, Wang Y, Li A, Wang Z, Zhang X, Yun T, Qiu L, and Yin Y (2016). Effects of fermented rapeseed meal on antioxidant functions, serum biochemical parameters and intestinal morphology 
in broilers. Food and Agricultural Immunology, 27(2): 182-193. DOI: https://www.doi.org/10.1080/09540105.2015.1079592

International Organization for Standardization (1988). Sorghum: Determination of tannin content. International Organization for Standardization. Available

at: https://www.iso.org/standard/17487.html

Khidr RE, Badri FBA, Hemid AA, and Elbaz AM (2017). Effect of acidic modulator on performance, gut health and some hematological parameters of broiler chickens, 16. BOKUSymposium Tierernährung. Available at: https://boku.ac.at/fileadmin/data/H03000/H97000/H97600/Symptag ungsbaende/BOKU Symposium 2017 incl.pdf

Liang R, Li Z, Xu G, and YANG Y (2012). Effects of fermentation feed on layer chicks growth performance and physiological indexes. Feed Review, 4: 5-8. Available at: https://en.cnki.com.cn/Article en/CJFDTotal-SLBL201204004.htm

Mahata ME, Ardi, and Rizal Y (2019). Selection of local microorganism solutions as crude fiber digester in Areca catechu L. Peel waste for producing poultry feed additives, International Journal of Poultry $\begin{array}{lll}\text { Science, } & 18(2): & 58-62 .\end{array}$ DOI: https://www.doi.org/10.3923/ijps.2019.58.62

Mathivanan R, Selvaraj P, and Nanjappan K (2006). Feeding of fermented soybean meal on broiler performance. International Journal of Poultry Science, 5: 868-872. DOI: https://www.doi.org/10.3923/ijps.2006.868.872

Mukherjee R, Chakraborty R, and Abhishek D (2016). Role of fermentation in improving nutritional quality of soybean meal - a review. Asian-Australasian Journal of Animal Sciences, 29: 15231529. DOI: https://www.doi.org/10.5713/ajas.15.0627

Nahashon SN, Nakaue HS, and Mirosh LW (1996). Nutrient retention and production parameters of Single Comb White Leghorn layers fed diets with varying crude protein levels and supplemented with direct-fed microbials. Animal Feed Science and Technology, 61(14): 17-26. DOI: https://www.doi.org/10.1016/0377-8401(96)00956$\underline{X}$

National Research Council (NRC) (1994). Nutrient Requirements of Poultry (9th rev. ed.) National Academy Press, Washington, DC., USA, pp.26-34. Available at: https://www.nap.edu/catalog/2114/nutrient-requirements-ofpoultry-ninth-revised-edition-1994

Paton AW, Morona R, and Paton JC (2006). Designer probiotics for prevention of enteric infections. Nature Reviews Microbiology, 4(3): 193-200. DOI: https://www.doi.org/10.1038/nrmicro1349

Rodriguez-Leon JA, Soccol CR, Pandey A, and Rodriguez DE (2008). Factors affecting solid-state fermentation. In Current developments in solid-state fermentation. Springer, New York, NY. pp. 26-47. Available at: https://link.springer.com/chapter/10.1007/978-0-387$\underline{75213-6 \quad 3}$

Santoso U, Tanaka K, and Ohtani S (1995). Effect of dried Bacillus subtilis culture on growth, body composition and hepatic lipogenic enzyme activity in female broiler chicks. British Journal of $\begin{array}{lll}\text { Nutrition, } & 74(4): & 523-529 .\end{array}$ https://www.doi.org/10.1079/bjn19950155

SAS Institute, (2002). SAS user's guide: Statistics. Cary, NC: SAS.

Shim Y, Shinde P, Choi J, Kim J, Seo D, Pak J, Chae B, and Kwon I (2010). Evaluation of multi-microbial probiotics produced by submerged liquid and solid substrate fermentation methods in broilers. Asian-Australasian Journal of Animal Sciences, 23(4): 521-529. DOI: https://www.doi.org/10.5713/ajas.2010.90446

Soumeh EA, Mohebodini H, Toghyani M, Shabani A, Ashayerizadeh A, and Jazi V (2019). Synergistic effects of fermented soybean meal and mannan-oligosaccharide on growth performance, digestive functions, and hepatic gene expression in broiler chickens. Poultry Science, 98: 6797-6807. DOI: https://www.doi.org/10.3382/ps/pez409

Sun H, Tang JW, Fang CL, Yao XH, Wu YF, Wang X, and Feng J (2013). Molecular analysis of intestinal bacterial microbiota of broiler chickens fed diets containing fermented cottonseed meal. Poultry Science, 92(2): 392-401. DOI: https://www.doi.org/10.3382/ps.2012-02533

Van Soest PJ, Robertson JB, and Lewis BA (1991). Methods for dietary fiber, neutral detergent fiber, and nonstarch polysaccharides in relation to animal nutrition. Journal of Dairy Science, 74: 35833597. DOI: http://dx.doi.org/10.3168/jds.S0022-0302(91)78551-2.

Wang JF, Zhu YH, Li DF, Wang Z, and Jensen BB (2004). In vitro fermentation of various fiber and starch sources by pig fecal inocula. Journal of Animal Science, 82(9): 2615-2622. DOI: https://www.doi.org/10.2527/2004.8292615x

Wang TY, Wu YH, Jiang CY, Liu Y (2010). Solid state fermented potato pulp can be used as poultry feed. British Poultry Science, 51: 229-234. DOI: https://www.doi.org/10.1080/00071661003781864

Willis WL, Isikhuemhen OS, and Ibrahim SA (2007). Performance assessment of broiler chickens given mushroom extract alone or in combination with probiotics. Poultry Science, 86(9): 1856-1860. DOI: https://www.doi.org/10.1093/ps/86.9.1856

Xu F, Zeng X, and Ding X (2012). Effects of replacing soybean meal with fermented rapeseed meal on performance, serum biochemical variables and intestinal morphology of broilers. Asian-Australasian Journal of Animal Sciences, 25(12): 1734-1741. DOI: https://www.doi.org/10.5713/ajas.2012.12249

Zhang J, Zhu J, Sun J, Li Y, Wang P, Jiang R, and Rahman MRT (2016). Effect of fermented feed on intestinal morphology, immune status, carcass and growth performance of Emei Black chickens. The FASEB Journal, 30(1): lb240. DOI: https://www.doi.org/10.1096/fasebj.30.1_supplement.lb240

Zhu XY, Zhong T, Pandya Y, and Joerger RD (2002). 16S rRNA-based analysis of microbiota from the cecum of broiler chickens. Applied and Environmental Microbiology, 68(1): 124-137. DOI: https://www.doi.org/10.1128/AEM.68.1.124-137.2002 